\title{
Predicting Aboveground Biomass Increment of Tropical Forests from Litter-fall
}

\author{
K. A. J. M. Kuruppuarachchi ${ }^{1}$ and G. Seneviratne ${ }^{2 *}$ \\ ${ }^{1}$ Department of Botany, The Open University of Sri Lanka, Nawala, Nugegoda, Sri Lanka \\ ${ }^{2}$ Institute of Fundamental Studies, Hantana Road, Kandy, Sri Lanka \\ Received: 08 August 2012 / Accepted 05 April 2013
}

\begin{abstract}
Predicting Aboveground Biomass Increment (ABI) of forests is important in evaluating primary productivity, and hence aboveground $\mathrm{C}$ sequestration rate and $\mathrm{C}$ policy implementation. Although there are direct methods such as remote sensing to predict the ABI, it is important to develop ground-based indirect methods, particularly for tropical forests, due to their stratification, complex structure and high diversity, which cannot be imaged properly using the direct methods. Present study developed regression models from a global database of tropical forests to predict the ABI from annual litter-fall. The new models could predict up to $92 \%$ and $66 \%$ of the variability of the ABI of the disturbed/managed and natural tropical forests, respectively, compared to $69 \%$ of the variability predicted by previous models, although they have used a part of the present database which was only available at that time. Field prediction of the new models by using a wet zone forest and a dry zone forest in Sri Lanka showed that the ABIs of the two forests (7-8 Mg $\left.\mathrm{ha}^{-1} \mathrm{yr}^{-1}\right)$ are towards the upper limit $\left(10 \mathrm{Mg} \mathrm{ha}^{-1} \mathrm{yr}^{-1}\right)$ of the tropical forests of the world. It is clear from this study that the new approach may be a better method for predicting the ABI in future research as well as tropical forest inventories. It is recommended however, that the models should be validated before their wider applications.
\end{abstract}

Key words: carbon sequestration, eddy covariance, managed forests, primary productivity

\section{INTRODUCTION}

Aboveground Biomass Increment (ABI) is the growth of aerial biomass of forests at a particular time interval. This parameter is important in evaluating primary productivity, and hence in evaluating aboveground $\mathrm{C}$ sequestration rate and $\mathrm{C}$ policy implementation. Currently, there are several methods applied to measure the ABI, namely remote sensing satellite techniques (Coops and Waring, 2001; Goetz et al., 2009; Zhang et al., 2012), Eddy covariance technique (Zhang et al., 2012) and inverse method (Zhang et al., 2012), which determine above ground biomass or biomass increments more directly. However, the direct measuring methods of the $\mathrm{ABI}$, determined from the space, have their own advantages and disadvantages, although they are promising options to ground-based methods (Hese et al., 2005). Alternatively, researchers have applied indirect modeling techniques to predict the ABI from measurable components such as annual litter-fall (Clark et al., 2001a; Neth et al., 2005). Predictive power of all these methods varies in their level of accuracy and the resolution at which data can be obtained. Thus, developing improved indirect techniques is equally important, since they can be used complementarily with direct techniques for better predictions. This is more important in the case of tropical forests because their complex structure and high diversity cannot be imaged properly from the direct techniques (Drake et al., 2003).

Using 13 tropical forest plots of a global database, Clark et al. (2001a) predicted $69 \%$ of the variability of the ABI from annual litter-fall. However, Shoo and Van Der Wal (2008) showed that such a relationship does not exist for the data of 37 lowland and upland forest plots of the same database. The highest explanatory power of their relationships was $19 \%\left(\mathrm{R}^{2}=0.19, \mathrm{P}=0.03\right)$. This shows that predicting $\mathrm{ABI}$ from the annual litterfall will not be reliable, unless an innovative procedure is developed. In the current study, data sorting of the global database and regression modeling were employed to investigate whether better relationships can be established between $\mathrm{ABI}$ and the litter-fall. Based on the relationships, the ABI of two tropical forests in Sri Lanka was forecasted from their annual litter-fall.

*Corresponding author's email: gaminis@ifs.ac.lk 


\section{MATERIALS AND METHODS}

Data source, analysis and modeling

Global database of the Oak Ridge National Laboratory (Clark et al., 2001b) and some other data available from various tropical forest studies (Spain, 1984; Amishi, 2006; Chave et al., 2008; Huston and Wolverton, 2009) were used in this study (Appendix I). These included rain forests, dry seasonal forests, tropical montane forests, tropical evergreen forests, mature secondary forests, Metrosideros forests, Terra firme, pine plantations and mahogany plantations, of which the geographical locations were central and south America, Caribbean islands, South and East Asia and West Africa. Altogether there were 30 forest sites. First, the data (ABI and annual litter-fall) were sorted by the following criterion. Forests with a recorded history of disturbance were considered as disturbed and managed (if planted after disturbance) forests. If there were no records of disturbances and management, those were considered as natural forests. Then, the two variables were plotted using X-Y scatter plot. Thereby, trends were identified and independent regression models were fitted using SAS (1998) software. Residual analysis was also performed to check the validity of the regression models.

\section{Predicting ABI for forests of Sri Lanka}

The ABI was predicted for a wet zone forest (Udawatta Kele forest reserve, ca. $750 \mathrm{~m}$ masl, mean annual rainfall for the last ten years: 1800 $\mathrm{mm}$ ) and a dry zone forest (Sigiriya sanctuary, ca. $150 \mathrm{~m}$ masl, mean annual rainfall for the last ten years: $1400 \mathrm{~mm}$ ) of Sri Lanka. To predict ABI, data on annual litter-fall were collected from permanent litter traps (Anderson and Ingram, 1993) constructed in the two forests. First, four 2 $\mathrm{x} 2 \mathrm{~m}$ plots were demarcated in random positions in each forest, by selecting grid coordinates on a map of the section of the forest by using a random number generator, and then by using Global Positioning System (GPS). Litter in the plots was removed and a $2 \mathrm{~mm}$ nylon mesh $(2 \times 2 \mathrm{~m})$ was fixed $20 \mathrm{~cm}$ above the plot as a litter trap. Then, the plot was fenced with thick polythene sheets (black and white) to protect from wild animals. Litter (both fine and coarse) fallen on the trap was collected monthly for one year (JanuaryDecember 2010), oven-dried $\left(65^{\circ} \mathrm{C}\right.$ for $\left.72 \mathrm{hrs}\right)$, and dry weight was recorded. Thereby, annual litter-fall by weight per unit area was estimated. This estimate was used to predict the ABI of the two forests from the models developed.

\section{RESULTS AND DISCUSSION}

There were 11 natural forests in the global database. First, a $2^{\text {nd }}$ degree polynomial relationship between annual litter-fall and the $\mathrm{ABI}$ was fitted to the dataset with $\mathrm{R}^{2}$ of 0.78 , which was significant at $1 \%$ probability level. Thereby, it was found that the model explained $78 \%$ of the variability of the actual ABI. However, when one outlier (a natural rainforest in India, Appendix I), which lay far from the line with a large residual value was removed. Based on visual observations, it was then possible to fit a significant, negative linear relationship (P $<0.01$ ) between the annual litter-fall $(\mathrm{X})$ and the $\mathrm{ABI}(\mathrm{Y})$ as given below, for 10 natural forests in the global database (Appendix I, Eq. 1 and Figure 1a), which explained $66 \%\left(R^{2}=0.66\right)$ of the variability of the actual ABI. Comparison of the two models for the smaller sum of squares (SS) revealed that the linear model was sufficient to explain the variability of the actual ABI. The residual plot of the linear model showed a lack of pattern, confirming its validity. Parameter estimates of the coefficient of $\mathrm{X}$ and the intercept were significant $(\mathrm{P}<0.05)$.

$$
\mathrm{Y}=-1.82 \mathrm{X}+14.2 ; \mathrm{R}^{2}=0.66(\mathrm{P}<0.01) \quad \text { Eq. } 1
$$

Using a similar analysis by removing one outlier (a palm-dominated floodplain in Puerto Rico) as above (Appendix I), it was possible to fit a linear model to 18 disturbed and managed forests (disturbed forests, plantations or monocultures). Its relationship between the annual litter-fall (X) and the $\mathrm{ABI}(\mathrm{Y})$ was positive, as given below (Eq. 2 and Figure 1b). It explained $92 \%$ of the variability of the actual ABI. Its residual plot confirmed its validity. Parameter estimate of the coefficient of $\mathrm{X}$ was significant $(\mathrm{P}<0.05)$.

$\mathrm{Y}=0.616 \mathrm{X} ; \mathrm{R}^{2}=0.92(\mathrm{P}<0.01) \quad$ Eq. 2

The opposite (i.e. negative and positive) relationships of the two types of forests could be attributed to a litter-fall-associated soil nutrient cycling issue. In the natural forests, in general, there is a relatively higher level of soil organic matter than that of the managed forests (Lai, 2004). Litter-fall and decomposition contribute organic matter with relatively high $\mathrm{C} / \mathrm{N}$ ratio to the top soil. 
(a)

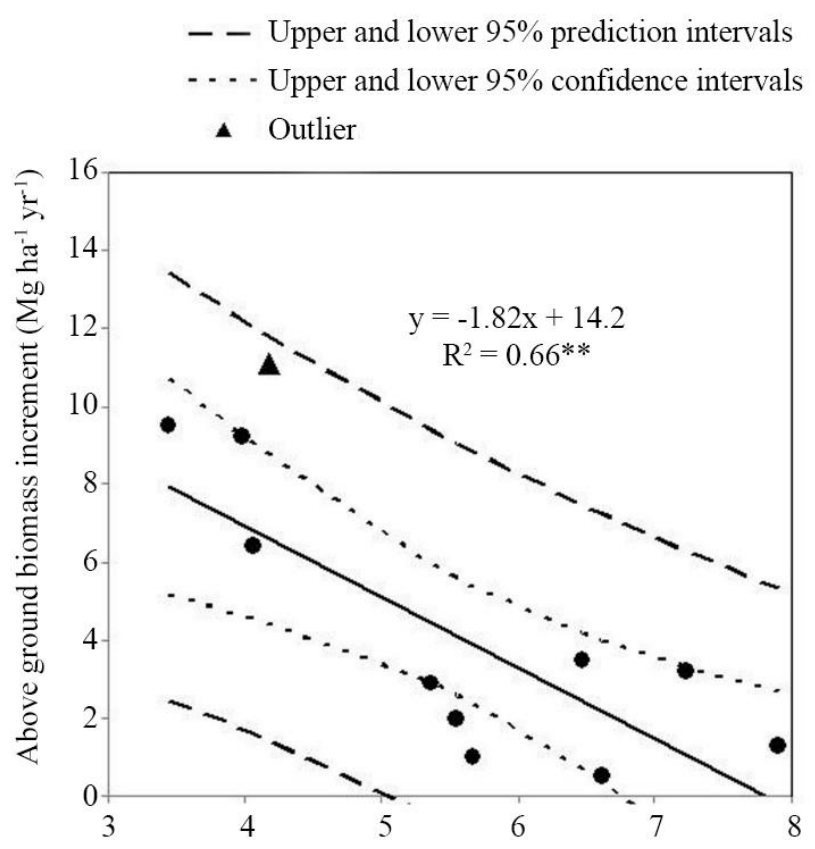

(b)

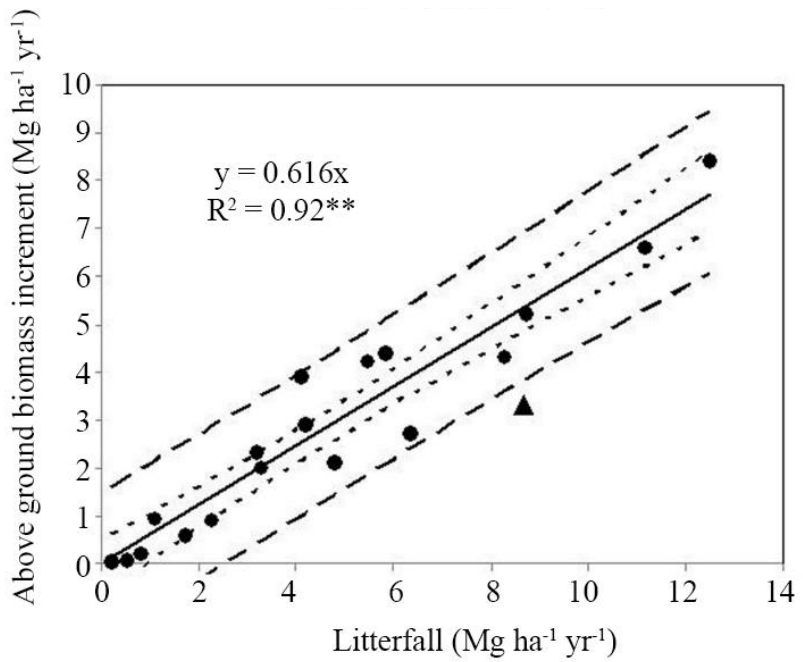

Figure 1. Relationships between annual litter-fall and above ground biomass increment for, (a) natural forests, and (b) disturbed/managed forests in the global tropical database.

** Significant at $1 \%$ probability level

Table 1. Annual litter-fall and predicted aboveground biomass increments (ABI) of the dry and wet zone forests in Sri Lanka, assuming that they are natural or disturbed and managed forests

\begin{tabular}{lccc}
\hline \multicolumn{1}{c}{ Forest } & $\begin{array}{c}\text { Annual litter-fall } \\
\left(\mathrm{Mg} \mathrm{ha}^{-1} \mathrm{yr}^{-1}\right)\end{array}$ & $\begin{array}{c}\mathrm{ABI}_{\mathrm{mf}} \\
\left(\mathrm{Mg} \mathrm{ha}^{-1} \mathrm{yr}^{-1}\right)\end{array}$ & $\begin{array}{c}\mathrm{ABI}_{\mathrm{nf}} \\
\left(\mathrm{Mg} \mathrm{ha}^{-1} \mathrm{yr}^{-1}\right)\end{array}$ \\
\hline Sigiriya sanctuary (Dry zone forest) & $11.8 \mathrm{a} \pm 0.6$ & 7.3 & -7.3 \\
Udawatthe Kele (Wet zone forest) & $12.5 \mathrm{a} \pm 0.6$ & 7.7 & -8.6
\end{tabular}

Mean \pm 1 SE. Means in the same column followed by the same letter are not significantly different at 5\% probability level, according to t-test. $\mathrm{ABI}_{\mathrm{mf}}$ and $\mathrm{ABI}_{\mathrm{nf}}$ are aboveground biomass increments predicted from the developed regression models, assuming that the forests are disturbed/managed forests or natural forests, respectively. 
This tends to immobilize soil nutrients in the decomposing organic matter, reducing nutrient availability to the forest trees (Seneviratne, 2002). Thus, the higher the litter-fall, the lower the soil nutrient availability is, leading to lesser ABI. However, in managed forests, there is relatively low soil organic matter content. High litter-fall helps to increase soil organic matter, thus contributing to increased nutrient release and ABI.

Predicted ABIs of the two forests based on the equations (Eqs. 1 and 2) above are given in Table 1. Values of annual litter-fall of the two forests, which were not significantly different $(p>0.05)$, fall within the range of disturbed and managed forests of the present database (i.e. $0.2-12.7 \mathrm{Mg}$ $\mathrm{ha}^{-1} \mathrm{yr}^{-1}$, Table 1 and Figure 1b). Therefore, it is clear that the two forests behave as disturbed and managed forests. Further, negative ABIs predicted from the equation of natural forests confirm that they are not natural forests (Table 1). This is also supported by the fact that the two forests have been historically disturbed for cultivation and tree planting (Perera, 2001; Munasinghe, 2003), and hence are managed forests. The ABIs of managed, disturbed or plantation forests in tropics have been reported to range from very low values up to ca. $10 \mathrm{Mg} \mathrm{ha}^{-1}$ $\mathrm{yr}^{-1}$ (IPCC, 2006; Fang et al., 2007; Vasconcelos et al., 2012). Values of the two forests are close to the upper limit of the range.

In previous research, the $\mathrm{ABI}$ of forest stands has been estimated based on the litter-fall, with the assumption that the litter-fall is proportional to the ABI (e.g. Clark et al., 2001a; Malhi et al., 2004). In contrast, our analysis showed that the annual litter-fall was well related to the ABI, when the database was separated into natural and disturbed/managed forests. Our models could predict up to $92 \%$ of the variability of the ABI, particularly in the disturbed and managed forests of the global tropical forests. The model developed by Clark et al. (2001a) could predict only $69 \%$ of the variability of the ABI, although they used a part of the present database. Thus, our approach is a better method for predicting the $\mathrm{ABI}$ in future research as well as tropical forest inventories. It is recommended however, that the models should be validated before their wider applications.

\section{ACKNOWLEDGEMENTS}

We are grateful to Ms. Kumuduni Karunaratne and Mr. M.A. Lal of the Institute of Fundamental
Studies for their assistance in sampling and laboratory preparations.

\section{REFERENCES}

Amishi, B.J., David, R.V. and Johnson, A.H. (2006). Litter quality and climate decouple nitrogen mineralization and productivity in Chilean, temperate rain forest. Soil Science Society of America Journal 70: 153-162.

Anderson, J.M. and Ingram, J.S.I. (1993). Tropical Soil Biology and Fertility: A Handbook of Methods. $2^{\text {nd }}$ Ed., CAB International, Wallingford, $220 \mathrm{p}$.

Chave, J., Olivier, J., Bongers, F., Châtelet, P., Forget, P.M., van der Meer, P., Norden, N., Riéra, B. and Dominique, P.C. (2008). Aboveground biomass and productivity in a rain forest of eastern South America. Journal of Tropical Ecology 24: 355- 366.

Clark, D.A., Brown, S., Kicklighter, D.W., Chambers, J.Q., Thomlinson, J.R., Ni, J. and Holland, E.A. (2001a). Net primary production in tropical forests: an evaluation and synthesis of existing field data. Ecological Applications 11: 371-384.

Clark, D.A., Brown, S., Kicklighter, D.W., Chambers, J.Q., Thomlinson, J.R., Ni, J. and Holland, E.A. (2001b). NPP tropical forest: consistent worldwide site estimates, 1967 1999. Data set. Available on-line [http://www.daac.ornl.gov] from the Oak Ridge National Laboratory Distributed Active Archive Center, Oak Ridge, Tennessee.

Coops, N.C. and Waring, R.H. (2001). The use of multi scale remote sensing imagery to derive regional estimates of forest growth capacity using 3-PGS. Remote Sensing of Environment 75: $324-334$.

Drake, J.B., Knox, R.G., Dubayah, R.O., Clark, D.B., Condit, R., Blair, J.B. and Hofton, M. (2003). Above-ground biomass estimation in closed canopy Neotropical forests using lidar remote sensing: factors affecting the generality of relationships. Global Ecology and Biogeography 12: 147-159.

Fang, S., Xue, J. and Tang, L. (2007). Biomass production and carbon sequestration potential in poplar plantations with different management patterns. Journal of Environmental Management 85: 672 - 679.

Goetz, S.J., Baccini, A., Laporte, N.T., Johns, T., Walker, W., Kellndorfer, J., Houghton, R.A. and Sun, M. (2009). Mapping and monitoring carbon stocks with satellite observations: a 
comparison of methods. Carbon Balance and Management 4: 2. doi:10.1186/1750-0680-4-2

Hese, S., Lucht, W., Schmullius, C., Barnsley, M., Dubayah, R., Knorr, D., Neumann, N., Riedel, T. and Schroter, K. (2005). Global biomass mapping for an improved understanding of the $\mathrm{CO}_{2}$ balance - the Earth observation mission carbon-3D. Remote Sensing of Environment 94: 94-104.

Huston, M.A. and Wolverton, S. (2009). The global distribution of net primary production: resolving the paradox. Ecological Monographs 79: 343-377.

IPCC (2006). IPCC guidelines for national greenhouse gas inventories. Prepared by the national greenhouse gas inventories programme. In: H.S. Eggleston, L., Buendia, K. Miwa, T. Ngara and K. Tanabe (Eds), Institute for Global Environmental Strategies. IPCC, Hayama, Japan.

Lai, R. (2004). Soil carbon sequestration in natural and managed tropical forest ecosystems. Journal of Sustainable Forestry 21: $1-30$.

Malhi, Y., Baker, T.R., Phillips, O.L., Almeida, S., Alvarez, E., Arroyo, L. (2004). The aboveground wood productivity and net primary productivity of 100 Neotropical forest plots. Global Change Biology 10: 563-59.

Munasinghe, J.E. (2003). State of Forest Genetic Resources Conservation and Management in Sri Lanka. Department of Forest. Colombo.
Neth, T.N., Mizoue, N. and Kai, S. (2005). Estimating forest biomass increment based on permanent sample plots in relation to wood fuel consumption: a case study in Kampong Thom Province, Cambodia. Journal of Forest Research 9: 117 - 123.

Perera, G.A.D. (2001). The secondary forest situation in Sri Lanka: a review. Journal of Tropical Forest Science 13: 768- 785.

SAS (1998). STAT User's Guide. Version 6. Cary, NC. SAS Institute, Inc.

Seneviratne, G. (2002). Litter controls on carbon sequestration. Current Science 82: 130-131.

Shoo, L.P. and Van Der Wal, J. (2008). No simple relationship between above-ground tree growth and fine-litter production in tropical forests. Journal of Tropical Ecology 24: 347350.

Spain, A.V. (1984). Litter and the standing crop of litter in three tropical Australian rain forests. Journal of Ecology 68: 833-848.

Vasconcelos, S.S., Zarin, D.J., Araújo, M.M. and de Souza Miranda, I. (2012). Aboveground net primary productivity in tropical forest regrowth increases following wetter dryseasons. Forest Ecology and Management 276: $82-87$.

Zhang, X., Zhao, Y., Ashton, M.S. and Lee, X. (2012). Measuring carbon in forests. In: M.S. Ashton, M.L. Tyrrell, D. Spalding and B. Gentry (Eds), Managing Forest Carbon in a Changing Climate, Springer, Amsterdam, Pp. 139-164. 
Appendix I. Tropical forest sites used in the study; their category and history of disturbance

\begin{tabular}{|c|c|c|c|c|}
\hline \multirow[t]{2}{*}{ Country } & \multirow[t]{2}{*}{ Forest type } & \multicolumn{2}{|c|}{ Forest category } & \multirow{2}{*}{$\begin{array}{l}\text { History of } \\
\text { disturbance }\end{array}$} \\
\hline & & Natural & Disturbed/managed & \\
\hline USA-Hawaii & Metrosideros forest & & $\sqrt{ }$ & Volcanic activity \\
\hline USA-Hawaii & Metrosideros forest & & $\sqrt{ }$ & Volcanic activity \\
\hline USA-Hawaii & Metrosideros forest & & $\sqrt{ }$ & Volcanic activity \\
\hline USA-Hawaii & Metrosideros forest & & $\sqrt{ }$ & Volcanic activity \\
\hline USA-Hawaii & Metrosideros forest & & $\sqrt{ }$ & Volcanic activity \\
\hline USA-Hawaii & Metrosideros forest & & $\sqrt{ }$ & Volcanic activity \\
\hline Mexico & Terra firme forest & & $\sqrt{ }$ & Erosion \\
\hline Mexico & Terra firme forest & & $\sqrt{ }$ & Erosion \\
\hline India & Rain forest & $\sqrt{ }$ & & \\
\hline India & Rain forest & $\sqrt{ }$ & & \\
\hline India & Rain forest & $\sqrt{ }$ & & \\
\hline USA-Hawaii & $\begin{array}{l}\text { Metrosideros polymorpha } \\
\text { dominated forest }\end{array}$ & & $\sqrt{ }$ & $\begin{array}{l}\text { Volcanic activity \& } \\
\text { Hurricane }\end{array}$ \\
\hline India & Rain forest $\uparrow$ & $\sqrt{ }$ & & \\
\hline Mexico & Terra firme forest & & $\sqrt{ }$ & Erosion \\
\hline Puerto Rico & Dry seasonal forest & & $\sqrt{ }$ & Deforestation \\
\hline Puerto Rico & Mature secondary & $\sqrt{ }$ & & \\
\hline USA-Hawaii & $\begin{array}{l}\text { Metrosideros polymorpha } \\
\text { dominated forest }\end{array}$ & & $\sqrt{ }$ & Volcanic activity \\
\hline Jamaica & Tropical montane forest & $\sqrt{ }$ & & \\
\hline Jamaica & Tropical montane forest & $\sqrt{ }$ & & \\
\hline Venezuela & Terra firme forest & & $\sqrt{ }$ & Deforestation \\
\hline USA-Hawaii & $\begin{array}{l}\text { Metrosideros polymorpha } \\
\text { dominated forest }\end{array}$ & & $\sqrt{ }$ & Volcanic activity \\
\hline Jamaica & Tropical montane forest & $\sqrt{ }$ & & \\
\hline Jamaica & Tropical montane forest & $\sqrt{ }$ & & \\
\hline Puerto Rico & Mature secondary & $\sqrt{ }$ & & \\
\hline Puerto Rico & Mature secondary & $\sqrt{ }$ & & \\
\hline Brazil & Terra firme forest & & $\sqrt{ }$ & Deforestation \\
\hline Puerto Rico & $\begin{array}{l}\text { Palm-dominated forest, } \\
\text { floodplain } \dagger\end{array}$ & & $\sqrt{ }$ & $\begin{array}{l}\text { Deforestation \& } \\
\text { flooding }\end{array}$ \\
\hline USA-Hawaii & $\begin{array}{l}\text { Metrosideros polymorpha } \\
\text { dominated forest }\end{array}$ & & $\sqrt{ }$ & Volcanic activity \\
\hline Puerto Rico & Mahogany plantation & & $\sqrt{ }$ & Deforestation \\
\hline Puerto Rico & Mahogany plantation & & $\sqrt{ }$ & Deforestation \\
\hline
\end{tabular}

$\uparrow$ outlier 